\title{
JOURNAL OFAVIATION
}

\section{Akıllı Yangın Söndürme Mühimmatının Sayısal Analizi}

\author{
Murat TOPTAŞ ${ }^{*}$ (D), Mehmet YILMAZ ${ }^{2}$ (D) \\ ${ }^{1,2}$ İnönü Üniversitesi, Mühendislik Fakültesi, Makine Mühendisliği Bölümü, Malatya, Türkiye
}

\begin{abstract}
Özet
Akıllı yangın söndürme mühimmatı (AYSM) yangınlarla havadan mücadele yöntemlerinde kullanılabilecek, yeni ve etkili bir üründür. Bu ürün NATO üyesi ülkelerin envanterinde bulunan bir harp mühimmatı olan MK-82 (havadan yere genel maksat bombası) tip mühimmatın tasarımına benzer tasarıma sahiptir. Tasarım ölçülerinin var olan bir harp mühimmatına benzemesi onu hava araçları üzerinde herhangi bir iyileştirme veya değiştirme yapmadan doğrudan hava aracına yükleme imkânı vermektedir. Bu çalışmanın amacı, insansız bir hava aracına yüklü mühimmatın, araca ait maksimum hız koşullarında ortaya çıkaracağı sürükleme katsayısının tespitidir. Hava aracının ulaşacağı maksimum hız değerinde AYSM'nin gövdesi üzerinde ortaya çıkacak basınç ve hiz profillerinin belirlenerek görselleştirilmesi amaçlanmıştır. Korunum denklemleri farklı türbülans modelleri kullanılarak sonlu elemanlar esasına dayalı olan Ansys Fluent yazılımı yardımıla çözülmüștür. Bilgisayar ortamında sanal bir rüzgâr tüneli kurulmuş farklı $y^{+}$değerleri kullanılarak mühimmata ait ağ optimizasyonu yapılmıștır. Türbülans modelleri olarak SpalartAllmaras (S-A) modeli, standart k- $\varepsilon$ modeli ve SST k- $\omega$ türbülans modeli kullanılmıştır. Bulunan sonuçlar MK-82 tip genel maksat bombasına ait literatür verileri ile karşılaştırılarak doğrulama yapılmıştır. AYSM için verilen hız ve irtifa koşullarında en uygun $\mathrm{y}^{+}$ değerinin 60 olduğu ve buna bağlı olarak ilk inflation katman kalınlığının $0.3 \mathrm{~mm}$ olması gerektiği hesaplanmıştır. Kullanılan türbülans modellerinden SST k- $\omega$ türbülans modeli en doğru sonucu vermiștir. Bu modele göre AYSM'nin sürükleme katsayısı 0.14633 olarak bulunmuştur. Bu model kullanılarak maksimum uçuş hızı için mühimmat gövdesi üzerinde meydana gelebilecek basınç ve hız profilleri elde edilmiştir. Elde edilen sonuçlar ileride yapılacak yapısal statik ve dinamik analizlerde kullanılacaktır.
\end{abstract}

Anahtar Kelimeler: Yangın Söndürme Mühimmatı, Akıllı Mühimmat, Hesaplamalı Akışkanlar Dinamiği (HAD), Türbülans Modelleri, Sürükleme Katsayıs1

Corresponding Author/SorumluYazar: Murat TOPTAŞ murat.toptas@inonu.edu.tr

Citation/Alıntı: Toptaş M., Yılmaz M. (2021). Akıllı Yangın Söndürme Mühimmatının Sayısal Analizi J. Aviat. 5 (1), 22-35.

ORCID: ${ }^{1}$ https://orcid.org/0000-0001-9368-5675 ; ${ }_{-}^{2}$ https://orcid.org/0000-0001-5025-1842

DOI: https://doi.org/10.30518/jav.900833

Gelis/Received: 22 Mart 2021 Kabul/Accepted: 25 Haziran 2021 Yayınlanma/Published (Online): 30 Haziran 2021

Copyright(C) 2020Journal of Aviationhttps://javsci.com - http://dergipark.gov.tr/jav 


\title{
Numerical Analysis of Smart Fire Extinguishing Ammunition
}

\begin{abstract}
Smart fire extinguishing ammunition (SFEA) is a new and effective product that can be used in aerial firefighting methods. This product has a design similar to the MK-82 (air-to-ground general purpose grenade) type ammunition, which is a war ammunition in the inventory of NATO member countries. Being the design dimensions similar to an existing warfare ammunitionallows it to be loaded directly onto the aircraft without any improvement or modification on the aircraft. The aim of this study is to determine the drag coefficient of ammunition loaded on an unmanned aerial vehicle at maximum speed conditions of the vehicle. It is aimed to determine and visualize the pressure and velocity profiles that will appear on the body of the AYSM at the maximum speed that the aircraft will reach. The conservation equations have been solved by using Ansys Fluent software based on finite elements by different turbulence models. A virtual wind tunnel was established in the computer environment and mesh optimization of the ammunition was performed using different $\mathrm{y}+$ values. SpalartAllmaras (S-A) model, standard k- $\varepsilon$ model and SST k- $\omega$ turbulence model were used as turbulence models. The results were compared with the literature data of the MK-82 type general purpose bomb and verified. It was calculated that the optimum y+ value for the speed and altitude conditions given for the AYSM is 60, and accordingly, the first inflation layer thickness should be $0.3 \mathrm{~mm}$. Among the turbulence models used, the SST k- $\omega$ turbulence model gave the most accurate result. According to this model, the drag coefficient of SFEA is 0.14633 . This model was used to determine pressure and velocity profiles that can occur on the ammunition body at maximum flight speed have been obtained. The obtained results will be used in future structural, static and dynamic analyzes.
\end{abstract}

Keywords: Fire Extinguishng Ammunition, Smart Ammunition, Computational Fluid Dynamics (HAD), Turbulence Models, Drag Coefficient.

\section{Giriş}

Kontrolsüz yanma reaksiyonlarının neden olduğu afetlere yangın adı verilir. Yangınlar başta can kayıpları olmak üzere geri dönüşü olmayan çok ciddi hasarlara neden olmaktadır. Özellikle ormanlar için birinci dereceden tehlike unsuru yangınlardır. Avrupa Orman Yangınları Bilgi Sistemi (EFFIS)'nde yer alan bir rapora göre 2000 ila 2017 y1lları arasında Avrupa ve ülkemizde meydana gelen orman yangınlarında 8.5 milyon hektar ormanlık alan yanmıştır. Bu rakam her yıl yaklaşık olarak yarım milyon hektara denk gelmektedir. Bu olaylar neticesinde 611 sivil ve itfaiyeci hayatını kaybetmiş ve 54 milyon euroya yakın ekonomik kayıp meydana gelmiştir [1].

Literatürde birçok yerde yangın üçgeni olarak adlandırılan ve bir yangının ortaya çıkmasına neden olan üç temel unsur bulunur. Bunlar yanıcı madde, yakıcı madde ve ısıdır. Bir şekilde bu üç elemandan birinin yangın ortamından uzaklaştırılması yangının sona erdirilmesini sağlar [2].

Yangınlarla mücadele günümüzde karadan ve havadan mücadele olmak üzere iki şekilde yapılmaktadır. Karadan yapılan mücadelede insan ve iş makineleri gibi geleneksel araçlar kullanılmaktadır [3]. Havadan mücadele ise 1950'li yıllardan sonra Kanada ve Amerika Birleşik
Devletleri'nde ortaya çıkan ve mücadelede uçak, helikopter benzeri hava araçlarının kullanımını esas alan bir mücadele yöntemidir.

Yangınlara havadan müdahale yöntemi özellikle hava araçlarının sahip olduğu hız faktörü ve arazi şartlarından bağımsız olarak havadan gözlem ve müdahale şansını vermesi gibi nedenlerden ötürü oldukça etkili bir yöntem olarak öne çıkmaktadır [4]. $\mathrm{Bu}$ yöntemin etkinliğini daha da arttırmak amacıyla özellikle hava araçları üzerinde bazı iyileştirmelerin yapıldığı, daha da ötesi son yıllarda hava araçlarının özellikle yangınlarla mücadele için özel olarak tasarlanmaya başlandığ 1 görülmektedir. Ayrıca bu yöntemin kullanılmaya başlandığı ilk zamanların aksine bugün hava araçlarından yangın bölgesi üzerine su veya topraktan başka söndürücü maddeler de atılmaya başlanmıştır. $\mathrm{Bu}$ maddeler genel olarak fosfat esaslı kimyasallar, köpük, jel veya toz formda yangın söndürme kimyasalları şeklindedir [5]. Bu maddelerin hava araçlarından yangın bölgesi üzerine bırakılmas1 operasyonu yangın bölgesinin söndürücü ve soğutucu maddeler ile bombardıman edilmesi olarak adlandırılır.

Orman yangınlarında hava araçları genellikle ağaç tepe yüksekliklerinin 60 metre kadar yukarısına kadar alçalarak yangın bölgesini 
bombardıman etmeye başlarlar [6]. Bu noktadan daha yüksek irtifalardan bırakılacak söndürücü madde gerek yangın bölgesi üzerinde meydana gelen sıcaklık kaynaklı hava akımları ve gerekse hava direnci gibi nedenlerden ötürü yangın bölgesine ulaşmadan havada dağılmakta ve metrekareye düşmesi gerekenden çok daha az miktarda maddenin bölgeye inmesine neden olmaktadır. Dolayısıyla söndürücü madde etkinliği azalmaktadır. Tersi durumda yani hava aracının yangın bölgesi üzerine daha fazla yaklaşması durumunda ise hava aracinın yangından etkilenerek kırım geçirmesi veya söndürücü maddenin çarpma etkisi ile bölgeye ulaşması neticesinde söndürme işlevinden çok söndürücünün sahip olduğu ağırlık nedeni ile bir takım zararlar ortaya çıkmaktadır.

Özetlemek gerekirse yangınlarla havadan yapılan mücadele yönteminde kullanılan söndürücü ve soğutucu maddelerin yeterli miktarda, doğru bir konumda ve güvenli bir mesafeden birakılmas1, çözülmeyi bekleyen önemli problemlerdir. $\mathrm{Bu}$ sorunları çözmek amacıyla farklı ülkelerde çeşitli çalışmalar yapılmıştır. Bu çalışmalardan ilki 2004 y1lında Rusya'da ortaya çıkmıştır. Çalışmaya konu olan ürünün ismi ASP-500'dür [7]. Esasında polietilen malzemeden üretilen ve varil şeklinde silindir bir tank içerisine $500 \mathrm{~kg}$ kadar söndürücü malzeme doldurulmuştur. Bu tank yangın bölgesine bir hava aracı ile yukarıdan atılmakta ve yere çarpan tank içerisinde bulunan patlayicı infilak ederek söndürücü maddenin dağılması sağlanmaktadır. Proje test aşamasından sonra hayata geçmemiştir. Bunun başlica nedeni tasarım ve çalışma prensibinde yapılmış olan bazı hatalardır. Öncelikle ürünün aerodinamik bir yapısı bulunmamaktadır. Bırakıldıktan sonra rüzgâr direncinden çokça etkilenmekte ve doğru hedefi bulamamaktadır. Bir diğer problem ise çalışma şekli ile alakalıdır. Ürün sadece yere çarptığında aktive olabilmektedir. Ancak yangin sadece zeminde ilerlemez. Bu konuda yapılan diğer bir çalışma ise 2017 yılında Çin'de ortaya çıkmıştır. Yangın söndürme roketleri diyebileceğimiz bu ürün çok namlulu roket atar benzeri bir sistemin itfaiye aracı gibi bir kaide üzerine monte edilmesinden ibarettir. Roketler maksimum 300 metre mesafedeki en fazla $60 \mathrm{~m}^{3}$ kapalı alanda meydana gelen yangınlara $3.6 \mathrm{~kg}$ söndürücü malzemeyi taşımaktadırlar [8]. Bu ürün de bir önceki gibi birçok problem ihtiva eden bir tasarıma sahiptir. Bunlardan ilki roketlerin doğal olarak katı yakıtlı birer roket motoru taşımasıdır. $\mathrm{Bu}$ motorlar birkez ateşlendiklerinde ihtiva ettikleri yakıt bitene kadar yanmaya devam ederler. Yangın bölgesi üzerine bu türden yanıcı ve patlayıcı bir malzemenin gönderilmesi, üstelik bunun kapalı alanlara atılması mevcut olan felaketi daha da kötü bir hale getirebilir. Ayrıca $3.6 \mathrm{~kg}$ bir söndürücü malzemeyi hedefine gönderebilmek için bunun on katı kadar bir roket yakıtı kullanılmas1 gerekir. Hedefleme için kullanılan ve roketlerin burun kısmına yerleștirilmiş olan bir takım sensörlerin de toplam maliyeti düşünüldügünde aslında bu projenin de efektif olmadığı görülmektedir. Ayrıca bu proje açık alanlarda meydana gelen yangınlarda kullanılamamaktadır.

ASP-500 ve yangın söndürme roketlerinden farklı olarak kapalı alanlarda ve alan içerisinde bulunan elektrik sigorta panoları benzeri yangının ortaya çıkması muhtemel alanlarda kullanılmak üzere yangın söndürme topları geliştirilmiştir [9]. Bu toplar yaklaşık 1-1.5 kg ağırlığında ve içerisinde yangını boğucu bir madde (amonyum monofosfat) bulunan, dışı PVC ile kaplı ve hemen PVC altında karabarut bulunan ürünlerdir. El ile doğrudan yangın üzerine atılabileceği gibi çoğu durumda yangının çıkmasının muhtemel olduğu noktaların üzerine bir aparat yardımı ile tutturulmaktadır. $\mathrm{Bu}$ ürün şu şekilde çalışır; yangının neden olduğu alevlerin etkisi ile topun dış kısmında bulunan PVC hizlıca erir ve PVC altında bulunan barut yanarak merkeze ulaşır. Merkezde bulunan bir miktar patlayıcı özellikteki kimyasal küçük bir patlama gerçekleştirerek amonyum monofosfatın çevreye saçılımını sağlar. $\mathrm{Bu}$ ise yangını boğarak alevleri sönmeye zorlar. $\mathrm{Bu}$ sistem bahsedildiği gibi hava araçlarından atımı mümkün olmakla birlikte açık alanlarda yüksek miktarda bulunan havayı kesmede ve yangını boğmada yetersizdir. Kapalı alanlarda ve küçük hacimli mekânlarda (elektrik panoları veya $25 \mathrm{~m}^{3}$ hacme sahip odalar gibi) alanlarda kullanılabilmektedir.

Tasarladığımız akıllı yangın söndürme mühimmatı (AYSM) ise bahsi geçen tüm problemlere çözüm sunan yeni bir üründür. $\mathrm{Bu}$ ürün NATO üyesi ülkelerin envanterinde bulunan MK82 (havadan yere genel maksat bombası) tip 
mühimmatın tasarımına benzer tasarıma sahiptir. $\mathrm{Bu}$ tasarım sayesinde ürün Rusya'da ortaya çıkmış olan ASP-500'ün aerodinamik hatalarından kurtulmaktadır. Ayrıca tasarım ölçülerinin var olan bir harp mühimmatına benzemesi onu hava araçları üzerinde herhangi bir iyileştirme veya değiştirme yapmadan doğrudan hava aracına yükleme imkânı vermektedir. Bu çalışmanın amacı, insansız bir hava aracına yüklü mühimmatın, araca ait maksimum hız koşullarında ortaya çıkaracağı sürükleme katsayısının bilgisayar analizi ile tespitidir. Hava aracının ulaşacağı maksimum hız değerinde AYSM'nin gövdesi üzerinde ortaya çıkacak basınç ve hız profillerinin belirlenerek görselleştirilmesi amaçlanmıştır. Korunum denklemleri, farklı türbülans modelleri kullanılarak sonlu elemanlar esasına dayalı olan Ansys Fluent 16.0 yazılımı yardımıyla çözülmüştür. Bilgisayar ortamında sanal bir rüzgâr tüneli kurulmuş farklı $y^{+}$değerleri kullanılarak mühimmata ait ă optimizasyonu yapılmıștır. Türbülans modelleri olarak Spalart Allmaras (S-A), standart k- $\varepsilon$ ve SST k- $\omega$ türbülans modelleri kullanılmıştır. Bulunan sonuçlar MK-82 tip genel maksat bombasına ait literatür verileri ile karşılaştırılarak doğrulama yapılmıştır. Kullanılan türbülans modellerinden SST k- $\omega$ türbülans modeli en doğru sonucu vermiştir. Bu model kullanılarak verilen hız büyüklüğü için mühimmat gövdesi üzerinde meydana gelebilecek basınç ve hız profilleri elde edilmiştir.

\section{Akıllı Yangın Söndürme Mühimmatı (AYSM)}

Ak1llı yangın söndürme mühimmatı gövde, burun konisi, kanat takımı, söndürücü - soğutucu malzeme, patlayıcı, fünye, elektronik donanım ve yazılımdan oluşmaktadır (Şekil 1):

a) Gövde: AYSM'ye ait gövde yap1s1, $60^{\circ}$ 'lik açısı olan $1504 \mathrm{~mm}$ uzunluğundaki 6 parçanın merkezi bir silindir etrafında dizilimi ile meydana gelmiştir (Şekil 2). Bu parçaların içleri söndürücü - soğutucu madde ile doldurulmak üzere boşluklara sahiptir. Gövde merkezinde bulunan silindirik boru $32 \mathrm{~mm}$ çapında olup içerisi patlayıc1 madde haznesi olarak tasarlanmıştır. Gövdeyi meydana getiren 6 boşluklu yapıdan biri kontrol kartı, batarya ve süspansiyon askılarını barındırır. Burun konisi ve kuyruk takımı gövde üzerine monte edilir. AYSM gövdesinin montajlı durumu Şekil 3'de gösterilmiştir.

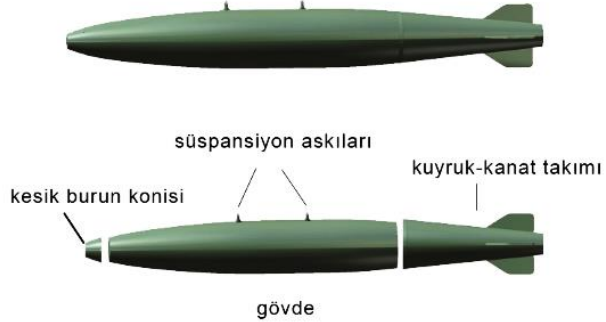

Şekil 1. Akıllı yangın söndürme mühimmatını (AYSM) meydana getiren elemanlar
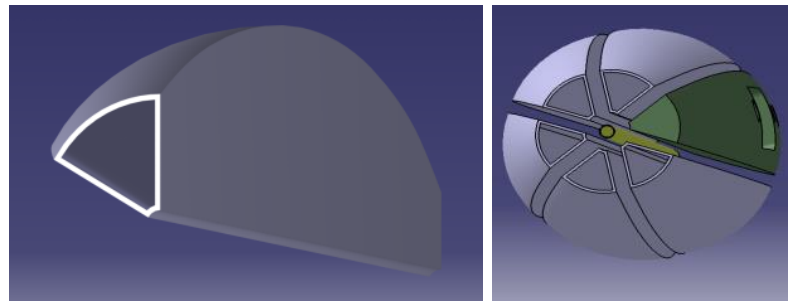

Şekil 2. AYSM gövde dilimli yapısına ait 3D model
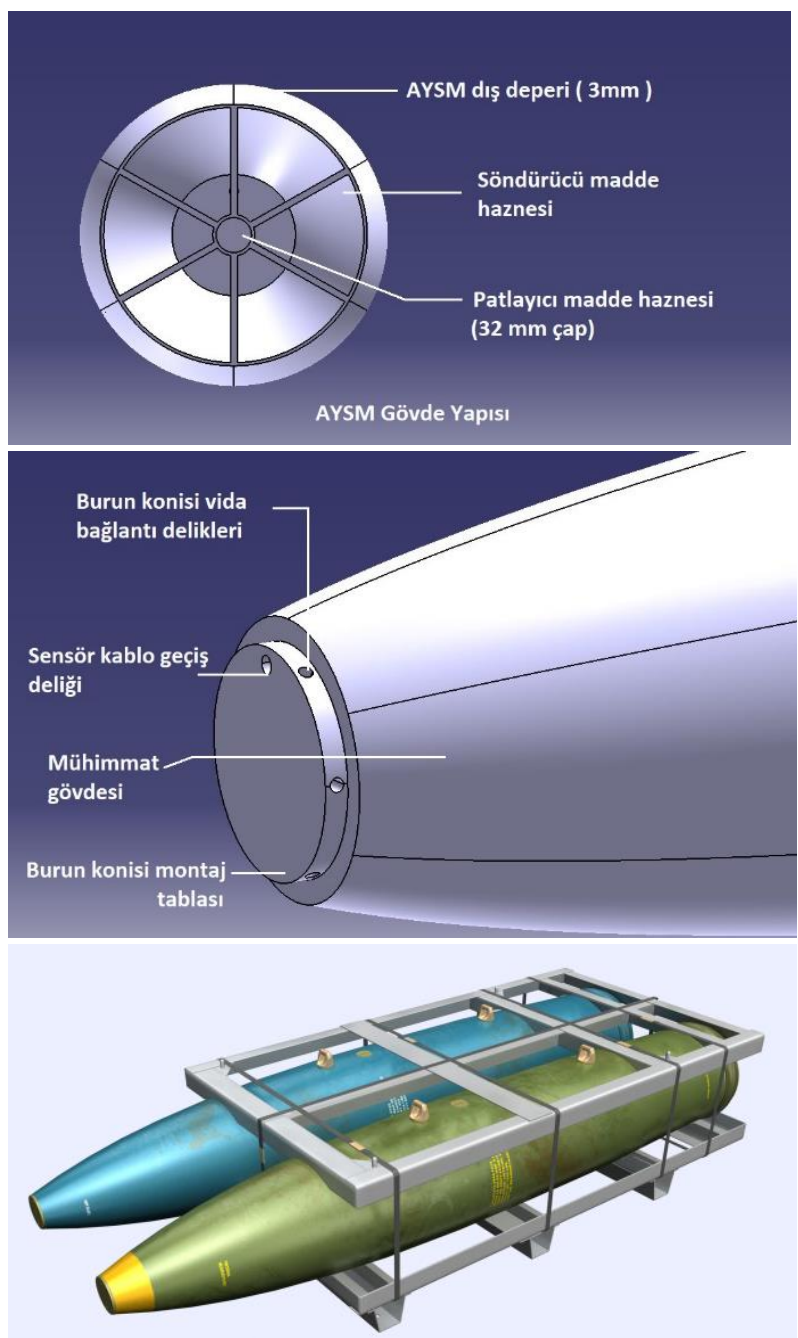

Şekil 3. AYSM gövdesinin montajlı durumu 
b) Burun Konisi: Burun konileri hava araçlarında hava direnci ile ilk karşılaşan elemanlardır. AYSM'ye ait burun konisi, üzerinde alev algılama, mesafe ölçüm ve çarpma sensörlerini barındıran kesik tip bir burun konisidir. Burun konisine ait ilk örneğin imalatı fiber katkılı Naylon 12 malzemeden yapılmıştır (MJF Baskı Teknolojisi ile 3D bask1). AYSM'nin seri üretiminde ise mühendislik alanında kullanılan, sağlam ve tokluk değeri yüksek bir termoplastik çeşidi olan polikarbonat hammaddenin (PC) kullanılması planlanmaktadır. Burun konisi ve gövdeye ait elemanların plastik enjeksiyon yöntemi ile üretimi gerçekleştirilecektir.

c) Kanat Takımı: AYSM 90 $0^{\circ}$ lik açısı olan dört adet kanata sahiptir. AYSM üzerinde kullanılan kanatlara ait geometri kırpılmış delta tip kanat geometrisidir (Şekil 4). Bu kanatların taban kenarı uzunlukları 320 $\mathrm{mm}$, firar kenar uzunlukları $120 \mathrm{~mm}$ ve uç kenar uzunlukları $80 \mathrm{~mm}$ 'dir. Kanatlar NACA benzeri herhangi bir aerodinamik profil yapısına sahip olmayıp $4 \mathrm{~mm} \mathrm{St-37}$ çelik sac levhadan lazer kesim yöntemi ile imal edilmişlerdir. Kanatlar yine aynı sac malzemenin şekillendirilmek suretiyle ortaya çıkarılan konik bir yapı üzerine kaynak yapılarak yerleştirilmişlerdir. Koni ve üzerine monte edilmiş kanatlardan oluşan bu takıma AYSM kanat takımı adı verilmiş olup bu takım gövdeye vidalarla monte edilerek sabitlenmiştir.
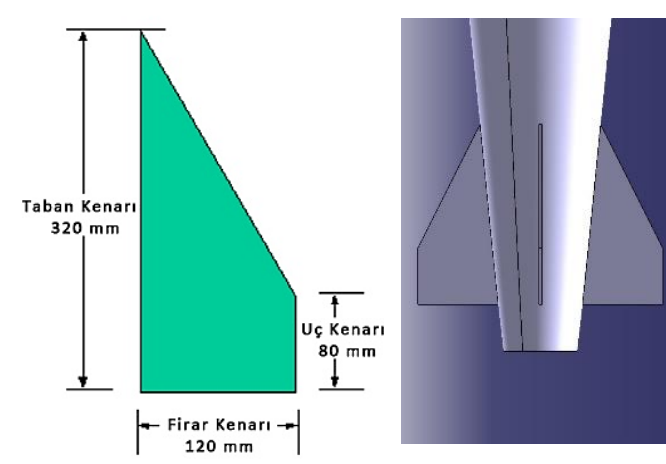

Şekil 4. AYSM kanat ölçüleri

d) Söndürücü-Soğutucu Malzeme: AYSM içerisinde üretimi ülkemizde yapılmakta olan, bor minerali esaslı ve toksisitesi olmayan toz formda bir kimyasal bulunur. $\mathrm{Bu}$ kimyasal diğer yangın söndürücülerin aksine aynı zamanda soğutma görevi de görmektedir. $\mathrm{Bu}$ maddenin orman yangınlarında kullanılan türü, yanmakta olan cisim üzerine atıldığında nesnenin sıcaklığını 10 saniye gibi kısa bir zaman aralığında $\quad 450^{\circ} \mathrm{C}^{\prime}$ den $\quad 24^{\circ} \mathrm{C}^{\prime}$ ye düşürmektedir. Aynı malzemenin metal ve kimyasal kaynaklı yangınlar için olanı da mevcut olup AYSM içerisinde kullanılabilmektedir.

e) Patlayıcı: AYSM gövde merkezinde bulunan silindirik hazne içerisinde dinamit patlayıc1 bulunur. Patlayıc1 elektrikli bir fünye marifetiyle detone edilir.

f) Fünye: Fünyeler patlayıcıları aktif hale getiren mekanik veya elektrikli düzeneklerdir. AYSM'de bulunan dinamit patlayıcı elektronik bir fünye marifetiyle patlatilir.

g) Elektronik Donanım: AYSM üzerinde alev, mesafe, çarpma, 6 eksen ivme ve Gyro sensörleri bulunur. Ayrıca bu sensörlerden gelen verilerin işlenerek uygun zamanda patlayıc1 malzemenin detone edilmesini sağlayan denetleyici bir kart mevcuttur. Tüm bu sensör ve kartların enerji ihtiyacını sağlayan $12 \mathrm{~V} \quad 1.3 \mathrm{~A}$ bir batarya da AYSM'nin elektronik ekipmanları arasında sayılabilir.

h) Yazilım: AYSM'nin hava aracindan ayrıldıktan sonraki süreçte görevini doğru bir şekilde yerine getirebilmesi için bir takım otonom kararlar alması gerekir. $\mathrm{Bu}$ kararları alırken ihtiyacı olan verileri sensörlerden alır. Üzerinde bulunan yazılım algoritması sayesinde bu verileri işler ve uygun noktada mühimmatın görevini icra etmesini sağlar. Yazılım C programlama dili ile yazılmıştır.

\section{Malzeme ve Yöntem}

\subsection{AYSM'nın 3 boyutlu modelinin oluşturulması}

AYSM, NATO mühimmatı olan havadan karaya genel maksatlı mühimmat tipi MK-82'nin boyutlarına göre oluşturulmuştur (Şekil 5). Üç boyutlu bir katı model oluşturmak için bilgisayar 
destekli bir tasarım uygulaması (Catia V5.R.21) kullanılmıştır (Şekil 6).

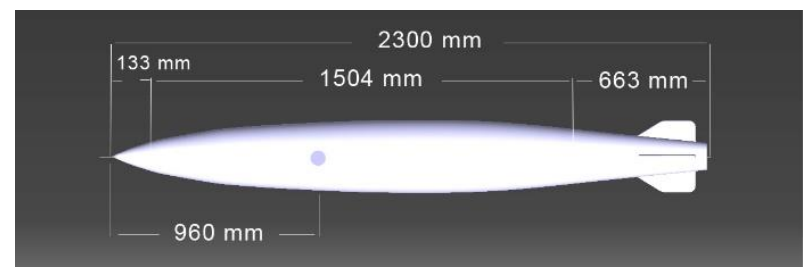

Şekil 5. MK-82 tipi havadan yere genel maksat mühimmatının metrik boyutları
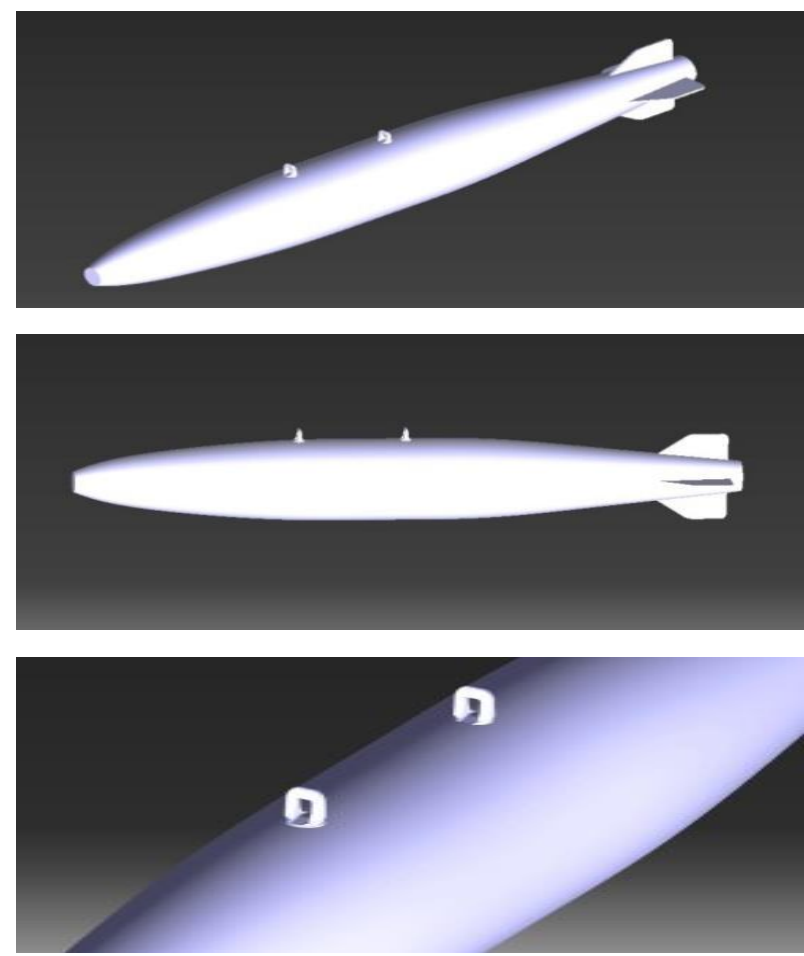

Şekil 6. Bilgisayar tabanlı 3 boyutlu tasarım uygulaması ile oluşturulan AYSM modeli

\subsection{Sanal Rüzgâr Tünelinin Oluşturulması}

Rüzgâr tünelleri, hava ile havada uçan bir cisim arasındaki etkileşimi taklit etmek için kullanılan geometrilerdir. Bilgisayar ortaminda analiz yapmak için tünel geometrisinin boyutları ve şekli belirlenerek sanal bir rüzgâr tüneli tasarlanmalıdır. HAD analizinde, bu geometri genellikle "mahfaza (enclosure)" olarak adlandırılır. Analizde kullanılacak rüzgâr tüneli geometrisi dikdörtgen prizma olarak seçilmiştir. Rüzgâr tüneli, tünel sınırlarının hava akışını etkilememesini sağlayacak bir boyutta olmalıdır. Bu nedenle sanal rüzgâr tüneli mahfaza uzunluğunun AYSM uzunluğunun 6 katı ve genişliğinin ise AYSM genişliğinin 4 katı olacak şekilde tasarlanmasının yeterli ve uygun olacağı görülmüştür [10]. Bu mahfaza SpaceClaim (katı modelleme CAD (bilgisayar destekli tasarım) yazılımı) ile oluşturulmuş ve üçte biri modelin önünde, üçte ikisi ise modelin arkasında olacak şekilde konumlandırılmıştır (Şekil 7).

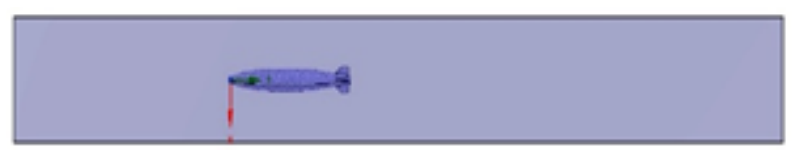

Şekil 7. Sanal rüzgâr tüneli mahfazasının görünümü

\subsection{Korunum Denklemleri ve Türbülans Modelleri}

$\mathrm{Bu}$ çalışmada akışın türbülanslı, üç boyutlu, sıkıştırılamaz ve sürekli rejimde olduğu kabul edilmiştir. Ansys Fluent yazılımı türbülans modellemesinde Eddy viskozitesi yaklaşımıyla, değişkenlerin ortalama değeriyle salınım değerlerinin toplamı olarak göz önüne alındığı Reynolds ortalamalı Navier-Stokes denklemlerini kullanmaktadır. $\mathrm{Bu}$ yaklaşımda hız bileşenleri aşağıdaki gibi ortalama değerleriyle salınım değerlerinin (çalkantı) toplamı şeklinde ifade edilirler [11]:

$$
u=\bar{u}+u^{\prime} \quad v=\bar{v}+v^{\prime}
$$

Türbülansl1, iki boyutlu, sıkıştırılamaz ve sürekli rejimdeki akışı ifade eden süreklilik, momentum ve enerji denklemleri kartezyen koordinatlarda aşağıdaki gibidir [11]:

Süreklilik denklemi:

$$
\frac{\partial(\overline{\rho u})}{\partial x}+\frac{\partial(\overline{\rho v})}{\partial y}=0
$$

x-Momentum denklemi:

$$
\begin{aligned}
& \frac{\partial(\overline{\rho u u})}{\partial x}+\frac{\partial(\overline{\rho v u})}{\partial y}=-\frac{\partial \bar{P}}{\partial x} \\
& +\frac{\partial}{\partial x}\left(\left(\mu+\mu_{t}\right) \frac{\partial \bar{u}}{\partial x}\right)+\frac{\partial}{\partial y}\left(\left(\mu+\mu_{t}\right) \frac{\partial \bar{u}}{\partial y}\right) \\
& +\frac{\partial}{\partial x}\left(\mu \frac{\partial \bar{u}}{\partial x}\right)+\frac{\partial}{\partial y}\left(\mu \frac{\partial \bar{v}}{\partial x}\right)
\end{aligned}
$$


y-Momentum denklemi:

$$
\begin{aligned}
& \frac{\partial(\overline{\rho u v})}{\partial x}+\frac{\partial(\overline{\rho v v})}{\partial y}=\rho g-\frac{\partial \bar{P}}{\partial y} \\
& +\frac{\partial}{\partial x}\left(\left(\mu+\mu_{t}\right) \frac{\partial \bar{v}}{\partial x}\right)+\frac{\partial}{\partial y}\left(\left(\mu+\mu_{t}\right) \frac{\partial \bar{v}}{\partial y}\right) \\
& +\frac{\partial}{\partial x}\left(\mu \frac{\partial \bar{u}}{\partial y}\right)+\frac{\partial}{\partial y}\left(\mu \frac{\partial \bar{v}}{\partial y}\right)
\end{aligned}
$$

Enerji denklemi:

$$
\begin{aligned}
& \frac{\partial}{\partial x}\left(\overline{\rho u} C_{p} \bar{T}\right)+\frac{\partial}{\partial y}\left(\overline{\rho v} C_{p} \bar{T}\right)=\frac{\partial}{\partial x}\left(\left(k_{i}+k_{t}\right) \frac{\partial \bar{T}}{\partial x}\right) \\
& +\frac{\partial}{\partial y}\left(\left(k_{i}+k_{t}\right) \frac{\partial \bar{T}}{\partial y}\right)
\end{aligned}
$$

$\mathrm{Bu}$ denklemlerde $\mathrm{k}_{\mathrm{t}}$ türbülanslı eddy iletkenliği ve $\mu_{\mathrm{t}}$ türbülanslı eddy viskozitesidir. $\mathrm{Bu}$ çalışmada korunum denklemleri farklı türbülans modelleri kullanilarak sonlu elemanlar esasına dayalı olan Ansys Fluent yazılımı yardımıyla çözülmüş ve elde edilen sonuçlar karşılaştırılmıştır. Kullanılan türbülans modelleri Spalart Allmaras (S-A) modeli, standart k- $\varepsilon$ modeli ve SST k- $\omega$ türbülans modelidir. Bu modeller aşağıda kısaca açıklanmıştır.

\subsubsection{Spalart Allmaras (S-A) modeli}

Spalart-Allmaras (S-A) modeli, kinematik eddy türbülans viskozitesi için modellenmiş taşınım denklemini çözen tek denklemli bir RANS modelidir. Modifiye edilmiş formdayken, eddy viskozitesinin cidar yakınında çözülmesi kolaydır. Spalart-Allmaras modeli, duvarla sınırlı akışları içeren havacılık uygulamaları için özel olarak tasarlanmıştır ve ters basınç gradyanlarına maruz kalan sınır tabakaları için iyi sonuçlar vermektedir. Ayrıca turbomakine uygulamalarında da popülerlik kazanmaktadır.

Orijinal biçiminde, model, etkin düşükReynolds sayılı bir modeldir ve sinır tabakanın viskoziteden etkilenen bölgesinin uygun şekilde çözülmesini gerektirir $\left(\mathrm{y}^{+} \sim 1\right.$ ağlar $)$. SpalartAllmaras modeli aerodinamik akışlar için geliştirilmiştir. Genel endüstriyel akışlar için kalibre edilmemiştir ve bazı serbest kayma akışları için, özellikle düzlem ve yuvarlak jet akışları için nispeten daha büyük hatalar üretir. Her tür karmaşık mühendislik akışlarına uygulanabilirliği konusunda iddialı bir model değildir. Homojen, izotropik türbülansın sönümlenmesini belirlemede güvenilir değildir [12].

\subsubsection{Standart k- $\varepsilon$ modeli}

k-epsilon türbülans modeli türbülanslı akış koşullarında ortalama akış özelliklerini simüle etmek için Hesaplamalı Akışkanlar Dinamiği'nde (HAD) kullanılan en yaygın modeldir. Standart k- $\varepsilon$ modeli, $k$ ve $\varepsilon^{\prime y i}$ çözen temel iki-transport denklemli bir modeldir. Bu iki denklem modeli türbülanslı enerjinin taşınımı ve yayılması gibi etkilerini hesaba katmaya yarar. Katsayılar deneysel olarak türetilmiştir; yalnızca tam türbülanslı akışlar için geçerlidir. Viskoz 1sıtma, kaldırma kuvveti ve sıkıştırılabilirliği hesaba katan seçenekler diğer k $\varepsilon$ modellerinde dikkate alınmaktadır [12]. Standart $\mathrm{k}-\varepsilon$ modelinde türbülans kinetik enerjisi $(\mathrm{k})$ ve onun yayılma hızı $(\varepsilon)$ olmak üzere türbülans viskozitesi ve türbülans iletkenliği şu şekilde ifade edilir [11]:

$\mu_{t}=C_{\mu} \rho \frac{k^{2}}{\varepsilon}$

$k_{t}=\frac{\mu_{t} C_{p}}{\sigma_{t}}$

Standart k- $\varepsilon$ türbülans modelinde iki boyutlu daimi akış için türbülans kinetik enerjisi $(\mathrm{k})$ ve türbülans kinetik enerjisi yayılma hızı denklemleri şu şekilde ifade edilmektedir [13]:

$$
\begin{aligned}
& \frac{\partial \overline{\rho u} k}{\partial x}+\frac{\partial \overline{\rho v k}}{\partial y}=\frac{\partial}{\partial x}\left(\frac{\mu_{t}}{\sigma_{k}} \frac{\partial k}{\partial x}\right)+\frac{\partial}{\partial y}\left(\frac{\mu_{t}}{\sigma_{k}} \frac{\partial k}{\partial y}\right) \\
& +\mu_{t} \Phi-\rho \varepsilon+\frac{C_{4} \beta \mu_{t}}{\sigma_{t}}\left(g \frac{\partial T}{\partial y}\right) \\
& \frac{\partial \overline{\rho u} \varepsilon}{\partial x}+\frac{\partial \overline{\rho v \varepsilon}}{\partial y}=\frac{\partial}{\partial x}\left(\frac{\mu_{t}}{\sigma_{\varepsilon}} \frac{\partial \varepsilon}{\partial x}\right)+\frac{\partial}{\partial y}\left(\frac{\mu_{t}}{\sigma_{\varepsilon}} \frac{\partial \varepsilon}{\partial y}\right) \\
& +C_{1 \varepsilon} \mu_{t} \frac{\varepsilon}{k} \Phi-C_{2} \rho \frac{\varepsilon^{2}}{k} \\
& +\frac{C_{\mu}\left(1-C_{3}\right) \beta \rho k}{\sigma_{t}}\left(g \frac{\partial T}{\partial y}\right)
\end{aligned}
$$

(9) nolu denklemdeki türbülans kinetik enerji üretimi $(\Phi)$ şu şekilde tanımlanmaktadır:

$$
\Phi=2\left[\left(\frac{\partial \bar{u}}{\partial x}\right)^{2}+\left(\frac{\partial \bar{v}}{\partial y}\right)^{2}\right]+\left(\frac{\partial \bar{u}}{\partial y}+\frac{\partial \bar{v}}{\partial x}\right)^{2}
$$


Türbülans model sabitleri ise $\mathrm{C}_{\mu}=0.09, \mathrm{C}_{1}=1.44$, $\mathrm{C}_{2}=1.92, \mathrm{C}_{3}=1.0, \mathrm{C}_{4}=0.0, \sigma_{\mathrm{k}}=1.0, \sigma_{\varepsilon}=1.30$ ve $\sigma_{\mathrm{t}}=0.9$ şeklindedir.

\subsubsection{SST k- $\omega$ türbülans modeli}

SST k- $\omega$ türbülans modeli, birçok aerodinamik uygulama için kullanılan iki denklemli bir eddyviskozite modelidir. Wilcox k- $\omega$ modeli, viskoz alt katmandaki akışı simüle etmek için çok uygundur. $\mathrm{k}-\varepsilon$ modeli ise duvardan uzak bölgelerdeki akış davranışını tahmin etmek için idealdir. SST (shear stress transport) formülasyonu, Wilcox $k-\omega$ ve kepsilon modellerini birleştiren hibrit bir modeldir. Bir harmanlama işlevi kullanarak duvarların yakınında kullanım için orijinal Wilcox modelini ve duvarlardan uzakta standart $\mathrm{k}-\varepsilon$ modelini birleştirir. $\mathrm{Bu}$, uygun modelin akış alanı boyunca kullanılmasını sağlar. Sınır tabakanın iç kısımlarında k- $\omega$ formülasyonunun kullanılması, modeli viskoz alt tabaka boyunca duvara kadar doğrudan kullanılabilir hale getirir; dolayısıyla SST k- $\omega$ modeli herhangi bir ekstra sönümleme fonksiyonu olmaksızın düşük-Re türbülans modeli olarak kullanılabilir. SST formülasyonu ayrıca serbest akışta k- $\varepsilon$ davranışına geçer ve böylece modelin giriş serbest akış türbülans özelliklerine fazla duyarlı olması şeklindeki yaygın k- $\omega$ problemini önler. SST k- $\omega$ modeli, ters basınç gradyanlı ve ayrılma bölgeli akışlarda iyi sonuçlar vermektedir. SST k- $\omega$ modeli, durma bölgeleri ve yüksek ivmeli bölgeler gibi büyük normal gerinmeye sahip bölgelerde biraz fazla yüksek türbülans seviyeler üretir. $\mathrm{Bu}$ eğilim, normal k- $\varepsilon$ modelinkinden çok daha az belirgindir $[14,15]$.

$\mathrm{k}-\omega$ modelinde türbülans kinetik enerjisi $(\mathrm{k})$ ve türbülans kinetik enerji özgül yayılma hızı $(\omega)$ olmak üzere türbülans viskozitesi şu şekilde ifade edilir $[11,16]$ :

$$
\begin{aligned}
& \omega=\frac{\varepsilon}{C_{\mu} k} \\
& \mu_{t}=\rho \frac{k}{\omega}
\end{aligned}
$$

$\mathrm{k}-\omega$ türbülans modelinde iki boyutlu daimi akış için türbülans kinetik enerjisi (k) ve türbülans kinetik enerji özgül yayılma hızı $(\omega)$ denklemleri şu şekilde ifade edilmektedir $[11,16]$ :

$$
\begin{aligned}
& \frac{\partial \overline{\rho u} k}{\partial x}+\frac{\partial \overline{\rho v} k}{\partial y}=\frac{\partial}{\partial x}\left(\left(\mu+\frac{\mu_{t}}{\sigma_{k}}\right) \frac{\partial k}{\partial x}\right) \\
& +\frac{\partial}{\partial y}\left(\left(\mu+\frac{\mu_{t}}{\sigma_{k}}\right) \frac{\partial k}{\partial y}\right)+\mu_{t} \Phi-C_{\mu} \rho k \omega \\
& +\frac{C_{4} \beta \mu_{t}}{\sigma_{k}}\left(g \frac{\partial T}{\partial y}\right) \\
& \frac{\partial \overline{\rho u} \omega}{\partial x}+\frac{\partial \overline{\rho v} \omega}{\partial y}=\frac{\partial}{\partial x}\left(\left(\mu+\frac{\mu_{t}}{\sigma_{\omega}}\right) \frac{\partial \omega}{\partial x}\right) \\
& +\frac{\partial}{\partial y}\left(\left(\mu+\frac{\mu_{t}}{\sigma_{\varepsilon}}\right) \frac{\partial \omega}{\partial y}\right)+\gamma \rho \Phi-\beta \prime \rho \omega^{2} \\
& +\frac{\left(1-C_{3}\right) \beta \rho}{\sigma_{t}}\left(g \frac{\partial T}{\partial y}\right)
\end{aligned}
$$

$\mathrm{Bu}$ modeldeki sabitler ise $\sigma_{\mathrm{k}}=2.0, \sigma_{\omega}=2.0$, $\gamma=0.555$ ve $\beta^{\prime}=0.075$ şeklindedir.

SST türbülans modeli $\mathrm{k}-\omega$ ve $\mathrm{k}-\varepsilon$ modellerinin avantajlarını birleştirmiştir. SST k- $\omega$ türbülans modelinde denklem (13)'de yer alan $\mathrm{P}_{\mathrm{t}}=\mu_{\mathrm{t}} \Phi$ terimi yerine $\mathrm{P}_{\mathrm{t}}=\min \left(\mu_{\mathrm{t}} \Phi, \mathrm{C}_{\mathrm{lm}} \varepsilon\right)$ terimi kullanılmaktadır. Ayrıca bu modelde türbülans kinetik enerji özgül yayılma hızı denkleminde fazladan

$$
\frac{\left(1-F_{1}\right) 2 \rho \sigma_{\omega 2}}{\omega}\left[\frac{\partial k}{\partial x} \frac{\partial \omega}{\partial x}+\frac{\partial k}{\partial y} \frac{\partial \omega}{\partial y}\right]
$$

terimi bulunmaktadır. Burada $F_{1}$ karışım fonksiyonu olup bu değer duvara yakın bölgelerde 1, uzak bölgelerde 0 olarak tanımlanmaktadır. $\mathrm{Bu}$ fonksiyon sayesinde SST türbülans modeli duvara yakın bölgelerde k- $\omega$ ve duvardan uzak bölgelerde k- $\varepsilon$ modeli gibi davranmakta, model katsayısı asağıdaki gibi verilmektedir:

$$
\varphi=F_{1} \varphi_{1}+\left(1-F_{1}\right) \varphi_{2}
$$

Burada $\varphi_{1}$ ve $\varphi_{2}$ terimleri sirasiyla k- $\omega$ ve k- $\varepsilon$ model katsayılarıdır. Model katsayıları $\mathrm{C}_{\mathrm{lmt}}=10^{15}, \mathrm{k}-\omega$ için $\sigma_{\mathrm{k}}=1.176, \sigma_{\omega}=2.0, \gamma=0.5532$ ve $\beta^{\prime}=0.075 ; \mathrm{k}-\varepsilon$ için $\sigma_{\mathrm{k}}=1.0, \quad \sigma_{\omega}=1.168, \quad \gamma=0.4403 \quad$ ve $\quad \beta^{\prime}=0.0828$ şeklindedir $[9,14]$.

\subsection{Sayısal Çözümleme}

HAD analizleri yapılırken sınır tabakanın doğru modellenmesi oldukça önemlidir. Çünkü hız ve sıcaklık gradyanları sınır tabaka içerisinde meydana gelir. AYSM yüzeyinden akmakta olan akışkan, 
AYSM ile aynı hıza sahiptir. AYSM'nin normali olan yönünde de ilerlendiğinde akışkan katmanlarının hızı giderek artar. Sınır tabaka içerisinde farklı hızlarda akan akışkan tabakaları arasında kayma gerilmeleri meydana gelir. Bunun nedeni viskozite ve türbülansların neden olduğu momentum değișimleridir. Dolayısıyla bu bölge doğru belirlenmediğinde bilgisayar ortamında yapılacak olan analiz sonuçları gerçek koşullarla eşleşmeyecektir. Özetle sınır tabaka hassas bir şekilde modellenmelidir. Bu amaçla ANSYS Fluent analiz yazılımı içerisinde sınır tabakanın istenilen sayı ve kalınlıkta katmanlara ayrilabilmesini sağlayan inflation tabakaları seçeneği bulunur. $\mathrm{Bu}$ tabakanın ilk kalınlığının belirlenmesi için sırasıyla aşağıdaki formüllere dayalı hesaplamalar yapılmıştır.

Öncelikle Reynolds sayısı aşağıdaki eşitlik kullanılarak hesaplanmıştır:

$$
R e=\frac{\rho \cdot V_{\infty} \cdot L_{c}}{\mu}
$$

Yüzey sürtünme katsayısı $\left(\mathrm{C}_{\mathrm{f}}\right)$ Reynolds sayısına bağlıdır ve aşağıdaki eşitlik kullanılarak hesaplanmıştır [16]:

$$
C_{f}=\left[2 . \log _{10}\left(R e_{x}\right)-0.65\right]^{-2.3}
$$

Yüzey sürtünme katsayısı kullanılarak cidar kayma gerilmesi (19) nolu eşitlik kullanılarak hesaplanmıştır:

$$
\tau_{w}=C_{f} \cdot \rho \frac{. V_{\infty}^{2}}{2}
$$

Sürtünme hızı aşağıdaki eşitlik kullanılarak hesaplanmıştır:

$$
U_{*}=\sqrt{\frac{\tau_{w}}{\rho}}
$$

Tüm bu hesaplamalardan sonra Şekil 8'e göre bir $\mathrm{y}^{+}$aralığı belirlenmiştir. Reynolds sayısına bağlı olarak, analizin türbülans kaynaklı kayma gerilmelerinin baskın olduğu tam türbülanslı bölgede yapılması gerektiği görülmüştür. En uygun $\mathrm{y}^{+}$değerini birbirleriyle karşılaştırarak belirlemek için beş farklı $(60,90,120,180,240)$ değer seçilmiştir.
Inflation tabakasına ait ilk kalınlığı belirleyebilmek için yukarıda seçilen her $\mathrm{y}^{+}$değeri için (21) no'lu denklem ayrı ayrı çözülmüştür:

$y=\frac{y^{+} \cdot \mu}{\rho \cdot U_{*}}$

Elde edilen sonuçlar her $\mathrm{y}^{+}$değeri için inflation katmanının ilk kalınlığıdır. Toplam katman sayısı 11 ve her katman arasındaki büyüme oranı 1.2 olacak şekilde ağ yapıları oluşturulmuştur. A $\breve{g}$ yapıları meydana getirilirken ortagonal ve skewness kalite değer aralıklarına riayet edilmiştir.

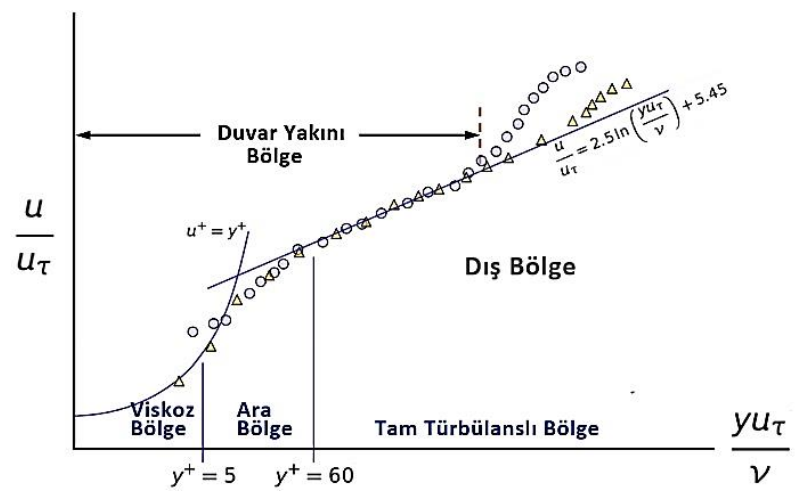

Şekil 8. Farklı akış bölgeleri için $\mathrm{y}^{+}$aralıkları [17].

Beş farklı $\mathrm{y}^{+}$değeri için ağ yapıları oluşturulduktan sonra RANS (Reynolds-Averaged Navier Stokes) modellerinden birisi olan Spalart Allmaras modeli ile hesaplanan sürükleme katsayıları, vertex basınçları ve statik basınçlar hesaplanmıştır. Sonuçlar arasında en küçük hata oranına bakılarak en doğru $\mathrm{y}^{+}$değeri belirlenmiştir. En doğru $\mathrm{y}^{+}$değeri için analiz, standart k- $\varepsilon$ ve SST $\mathrm{k}-\omega$ türbülans modelleri için tekrarlanmıştır. Üç farklı türbülans modeli için hesaplanan sonuçlar Avustralya Savunma Bilim ve Teknoloji Departmanı tarafindan yayınlanan bir dökümandan (Aerodynamic Database for the Mk 82 General Purpose Low Drag Bomb [18]) alınan verilerle karşılaştırılarak bir doğrulama çalışması gerçekleştirilmiştir.

\section{Bulgular ve Tartışmalar}

\subsection{Analiz Kosulları}

Analiz insansiz bir hava aracına ait maksimum seyahat koşulları için yapılmıştır (Tablo 1). Bu koşullarda AYSM üzerindeki akışın Reynolds sayıs $1.3 \times 10^{7}$ olarak hesaplanmıştır. Bu koşullarda akış tam türbülanslı bir akıştır. 
Tablo 1. Analiz paramatreleri

\begin{tabular}{lc}
\hline \multicolumn{1}{c}{ Parametre } & Değerler \\
\hline Serbest akım hızı & $86 \mathrm{~m} / \mathrm{s}$ \\
Yoğunluk & $1.205 \mathrm{~kg} / \mathrm{m}^{3}$ \\
Dinamik viskozite & $1.82 \times 10^{-5} \mathrm{~kg} / \mathrm{m} . \mathrm{s}$ \\
Mühimmat uzunluğu & $2.3 \mathrm{~m}$ \\
Mach sayısı & 0.25 \\
\hline
\end{tabular}

\subsection{Uygun A $\breve{g}$ Yapısının ve Türbülans Modelinin Belirlenmesi}

Farklı y+ değerleri için inflation katmanlarının hesaplanan ilk katman kalınlıkları Tablo 2'de verilmiştir. Elde edilen ă̆ yapıları Şekil 9'da gösterilmiştir.

Tablo 2. $\mathrm{y}^{+}$değerlerine göre tahmini ilk katman kalınlıklanı

\begin{tabular}{cc}
\hline $\mathbf{y}^{+}$ & $\begin{array}{c}\text { Hesaplanan ilk katman kalınlıkları } \\
(\mathbf{y})(\mathbf{m m})\end{array}$ \\
\hline 240 & 1.20 \\
180 & 0.90 \\
120 & 0.60 \\
90 & 0.45 \\
60 & 0.30 \\
\hline
\end{tabular}

Spalart Allmaras RANS türbülans modeli kullanılarak sürükleme katsayıları, vertex basınçları ve statik basınçlar elde edilmiştir. Bu sonuçlara göre optimum $\mathrm{y}^{+}$değerinin 60 olduğu belirlenmiştir. Spalart Allmaras RANS türbülans modeli dışında Standart k- $\varepsilon$ ve SST k- $\omega$ türbülans modelleri kullanılarak sürükleme katsayıları, tepe basınçları ve statik basınçlar elde edilmiştir. Standart k- $\varepsilon$ ve SST k- $\omega$ türbülans modelleri ile çözümleme yapilırken $\mathrm{y}^{+}$değeri olarak optimum değer olan 60 değeri seçilmiştir.

Sürükleme katsayıları MK-82 mühimmatı için literatürde olan $\mathrm{C}_{\mathrm{d}}$ direnç katsayıları ile karşılaştırılmış ve en uygun türbülans modelin SST k- $\omega$ türbülans modeli olduğu belirlenmiştir. SST k- $\omega$ türbülans modeli kullanılarak elde edilen direnç katsayısı, vertex basıncı ve statik basınç değerleri Tablo 3'de verilmiştir.

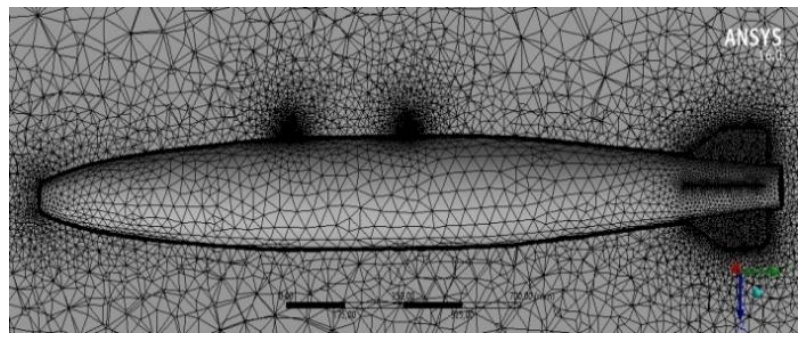

(a)

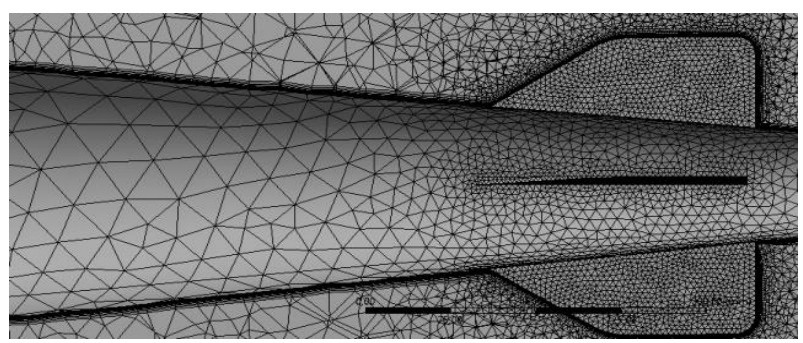

(b)

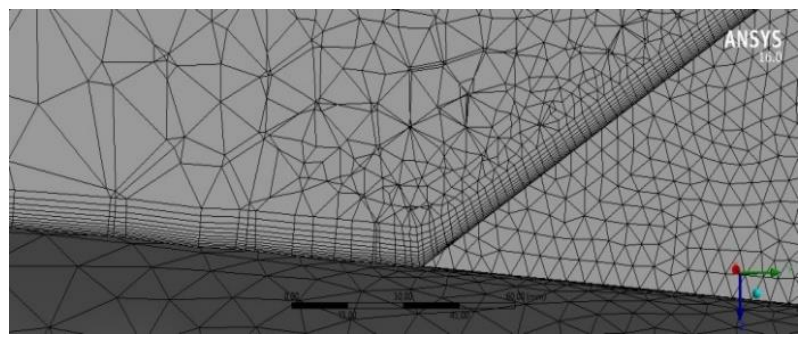

(c)

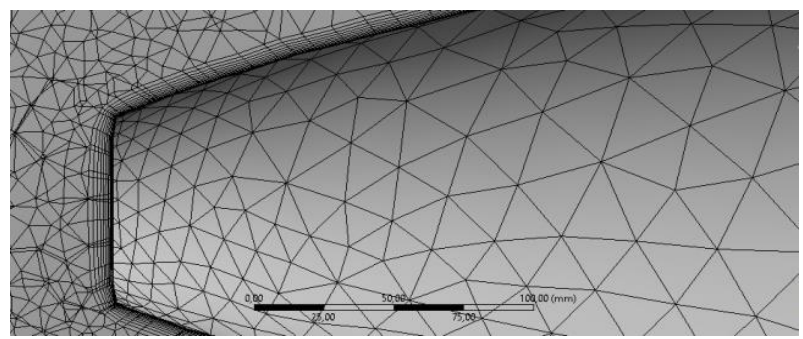

(d)

Şekil 9. AYSM'ye ait ağ ve inflation katmanları

Tablo 3. SST k- $\omega$ türbülans modeli sonuçları

\begin{tabular}{cc}
\hline Parametre & SST k $-\boldsymbol{\omega}$ \\
\hline Direnç Katsayısı $\left(\mathrm{C}_{\mathrm{d}}\right)$ & 0.14633 \\
Vertex Basıncı $(\mathrm{Pa})$ & 4806.10 \\
& -9978.93 \\
Statik Basınç $(\mathrm{Pa})$ & 4853.77 \\
\hline
\end{tabular}




\subsection{Statik Basınç Dağılımı}

Mühimmat gövdesi üzerindeki basınç dağılımının incelenmesi oldukça önemlidir. Toplam direnç katsayısı, sürtünme direnç katsayısı ve basınç direnci katsayısının toplamına eşittir. Mühimmat gövdesi üzerindeki basınç dağılımı basınç direncinin büyüklügünü belirler. AYSM gövdesi üzerindeki statik basınç dağılımı Şekil 10'da verilmiştir. Bernoulli ilkesi, sürtünmesiz bir akış boyunca, hızda gerçekleşen bir artışın aynı anda ya basınçta ya da akışkanın potansiyel enerjisinde azalmaya neden olduğunu ifade eder. Şekil 10a10d'den hızın düşük olduğu yerlerde basıncın arttığ görülmektedir. Mühimmatın ön bölgesi basıncın en yüksek olduğu bölgedir. Mühimmat etrafindaki basınç dağılımı incelendiğinde burun k1smı ve süspansiyon askılarının akışa dönük ön yüzlerinde basıncın çok yükseldiği ve bu bölgelerde durma noktası oluştuğu görülmektedir $\left(\sim 5 \times 10^{3} \mathrm{~Pa}\right)$ (Şekil 10b). Süspansiyon askılarının içerisinde bulunan boşluklardan ve askıların üst kısımlarından geçen akış hızlanmakta ve bunun sonucu oluşan basınç en düşük olmaktadır ( -9.5x10 Pa) (Şekil 10c). Ayrıca kanat bölgesinde kanatçıkların ön yüzeylerinde basınç artmakta $\left(\sim 1.7 \times 10^{3} \mathrm{~Pa}\right)$, ancak bu artış burun kısmı ve süspansiyon askılarının akışa dönük ön yüzlerindeki kadar yüksek olmamaktadır (Şekil 10d).

\subsection{Hız Dağılımı}

Bernoulli ilkesi, sürtünmesiz bir akış boyunca toplam enerjinin korunacağını, hızın arttığı yerde basıncın düşeceğini ve tersi olarak da basıncın düştüğü yerde hızın artacağını belirtmektedir. Kısaca ifade etmek gerekirse, basınç dağılımı ile hız dağılımı ters orantılıdır. AYSM gövdesi üzerindeki hız dağ 1 lımı Şekil 11'de verilmiştir. Akış alanı içinde, AYSM'ndan çok uzaktaki akışa serbest akış denir. Henüz mühimmatın hareket alanına girmemiş hava akımları paralel durumdadır, hareket alanı içindekiler kompleks hareket sergilerler. Mühimmat geometrisi göz önüne alındığında hızın en yüksek olduğu bölge beklenildiği gibi mühimmatın burun ve kuyruk kısmı dışındaki gövde bölgesidir. En yüksek hızlar süspansiyon askıları civarında elde edilmektedir.

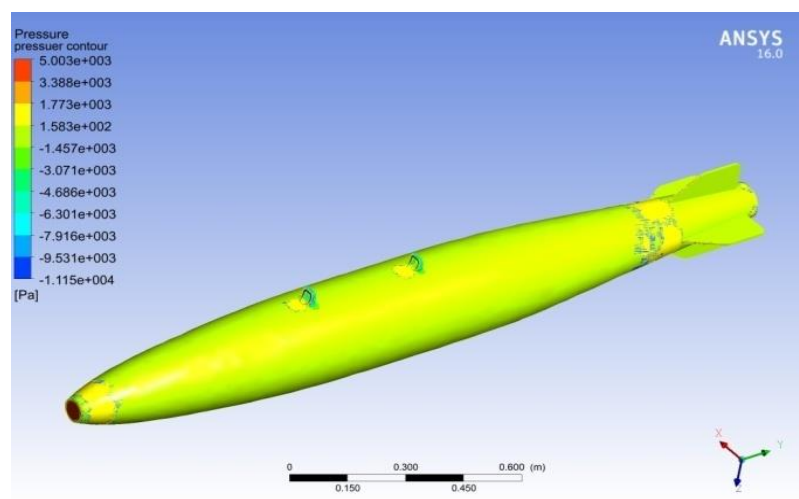

(a)

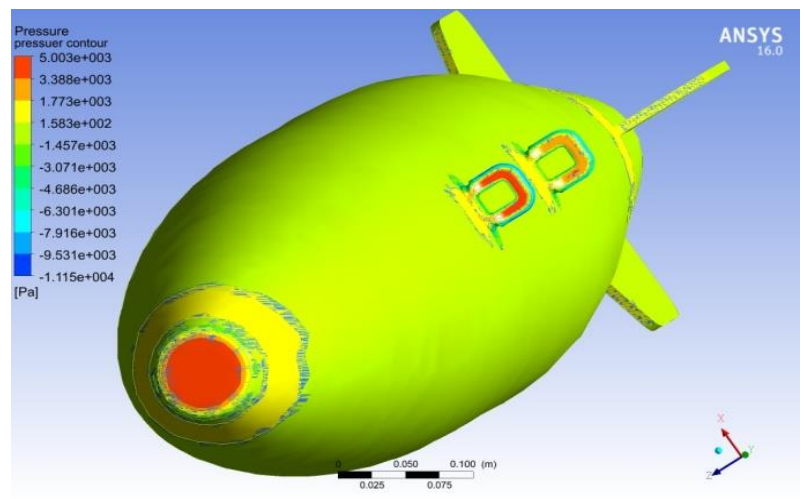

(b)

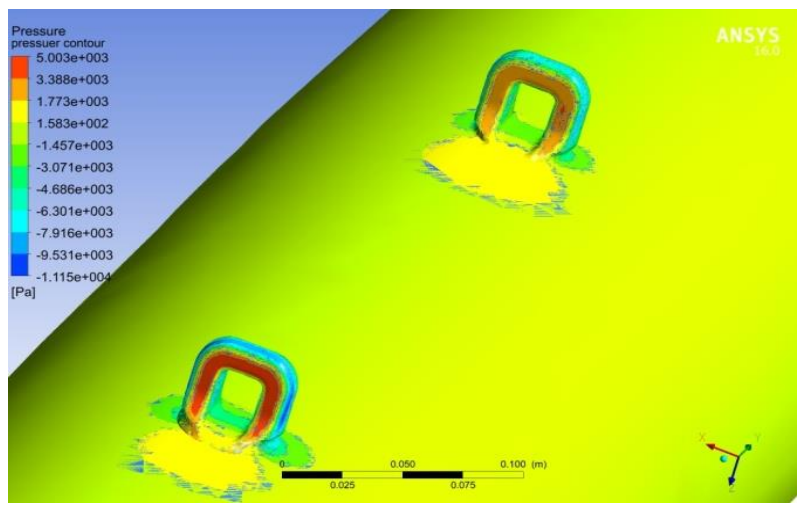

(c)

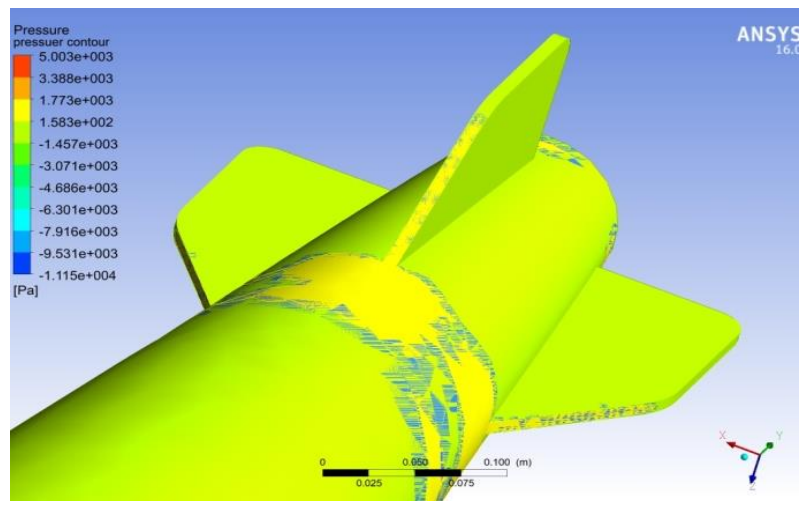

(d)

Şekil 10. AYSM gövdesi üzerindeki statik basınç dağ 1 lımı. 
Burun kısmı üzerindeki hız dağılımı Şekil 11b'de, süspansiyon askıları etrafındaki hız dağılımı Şekil 11c'de, kuyruk kısmı etrafındaki hız dağılımı Şekil 11 d'de ayrıntılı olarak gösterilmiştir. Basıncın çok yüksek olduğu burun kısmının ön taraflarında hızın oldukça düşük olduğu görülmektedir (Şekil 11b). Süspansiyon askılarının içerisinde bulunan boşluklardan ve askıların üst kısmından geçen akış oldukça hızlanmaktadır $\left(\sim 1.3 \times 10^{2} \mathrm{~m} / \mathrm{s}\right)$ (Şekil 11c). Şekil 11d'den görüldüğü gibi kanat bölgesinde kanatçıkların ön yüzeylerinde hız oldukça düşmektedir. Şekil 11d'de ayrıca kuyruk kısmının etrafinda oluşan ayrılma bölgesi ve ard izi bölgesi gösterilmiştir. Bu bölgelerin incelenmesi özellikle ard izi bölgesinde hızın düşük olduğunu ve kompleks davranış sergilediğini göstermektedir. Ancak mühimmatın aerodinamik tasarımı ayrılma ve ard izi bölgelerinin büyük olmasını engellemiş ve böylece basınç direncinin yüksek olmasına mani olmuştur.

\section{Sonuçlar}

Tarafımızca geliştirilen akıllı yangın söndürme mühimmatı (AYSM) yangınlarla havadan mücadele yöntemlerinde kullanılabilecek, yeni ve etkili bir üründür. $\mathrm{Bu}$ ürün NATO üyesi ülkelerin envanterinde bulunan bir harp mühimmatı olan MK-82 (havadan yere genel maksat bombasi) tip mühimmatın tasarımına benzer tasarıma sahiptir. Tasarım ölçülerinin var olan bir harp mühimmatına benzemesi onu hava araçları üzerinde herhangi bir iyileştirme veya değiştirme yapmadan doğrudan hava aracına yükleme imkânı vermektedir. Bu çalışmada, insansız bir hava aracına yüklü mühimmatın, araca ait maksimum hız koşullarında ortaya çıkaracağı sürükleme katsayısı belirlenmiş ve hava aracının ulaşacağı maksimum hız değerinde AYSM'nin gövdesi üzerinde oluşan basınç ve hız profilleri elde edilmiştir. Korunum denklemleri farklı türbülans modelleri kullanılarak sonlu elemanlar esasına dayalı olan Ansys Fluent yazılımı yardımıyla çözülmüştür. Türbülans modelleri olarak SpalartAllmaras (S-A) modeli, standart k- $\varepsilon$ modeli ve SST k- $\omega$ türbülans modeli kullanılmıştır. Çalışma sonucunda aşağıdaki bulgular elde edilmiștir:

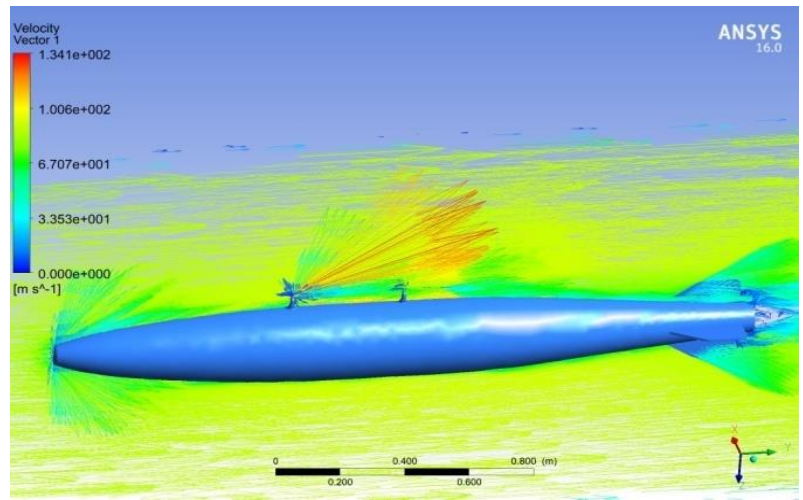

(a)

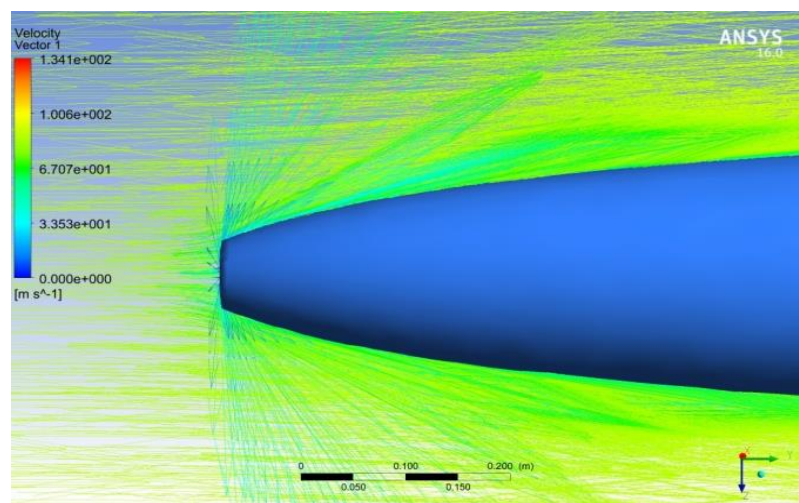

(b)

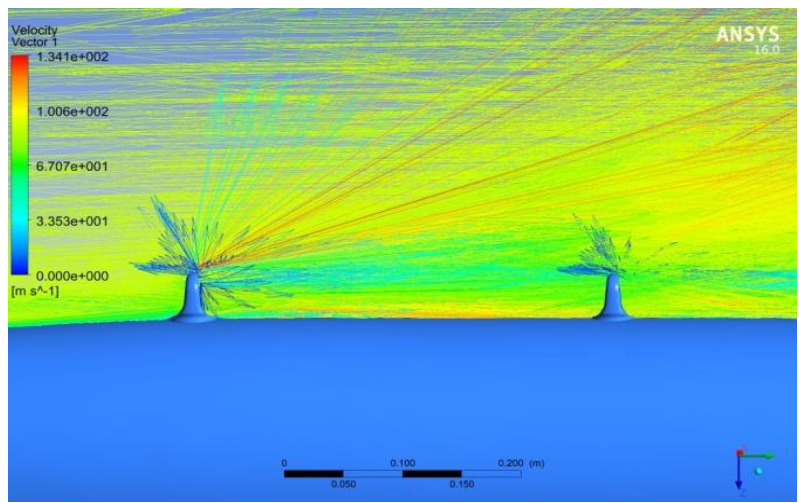

(c)

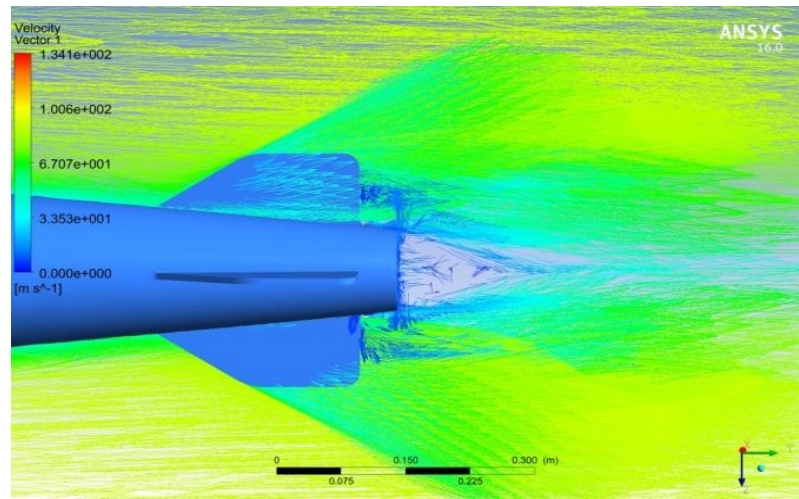

(d)

Şekil 11. AYSM gövdesi üzerindeki hız dağılımları. 
(a) Bir ağ yapıs1 oluşturulurken inflation katmanının ilk katman kalınlığının belirlenmesinde boyutsuz $\mathrm{y}^{+}$değeri oldukça önemlidir ve doğru bir değer kullanılmalıdır. Çalışmanın sonucu literatür değerleri ile karşılaştırıldığında AYSM için verilen hız ve yüksseklik koşullarında yapılan analiz için en uygun $\mathrm{y}^{+}$değerinin tam türbülasnslı bölgenin başlangıcı olan $\mathrm{y}^{+}=60$ olduğu ve bu değer için sınır tabaka modellemesinde kullanılacak ilk katman kalınlığının (y değeri) $\quad 0.3 \mathrm{~mm} \quad$ olması gerektiği görülmüştür.

(b) $\mathrm{Bu}$ çalışmada SpalartAllmaras (S-A) modeli, standart k- $\varepsilon$ modeli ve SST $\mathrm{k}-\omega$ türbülans modeli kullanılmış, bu türbülans modellerinden SST k- $\omega$ türbülans modeli en doğru sonucu vermiştir.

(c) SST k- $\omega$ türbülans modeli kullanılarak maksimum uçuş hızı için mühimmat gövdesi üzerinde meydana oluşan basınç ve hız profilleri elde edilmiştir. Mühimmatın aerodinamik tasarımı ayrılma ve ard izi bölgelerinin büyük olmasını engellemiş ve böylece basınç direncinin yüksek olmasına mani olunmuştur.

(d) SST k- $\omega$ türbülans modeli kullanılarak yapılan analizde sürükleme katsayısının 0.14633 olduğu bulunmuştur.

(e) Mühimmat gövdesi üzerinde meydana gelen maksimum statik basıncın burun ve taşıma halkalarının akışa dik olan yüzeylerinde meydana geldiği görülmüştür. Statik basınç -9978.93 $\mathrm{Pa}$ (minimum), +4853.77 $\mathrm{Pa}$ (maksimum) aralığında değişmektedir.

(f) $\mathrm{Bu}$ çalışma sonucunda elde edilen boyutsuz bir değer olan $\mathrm{y}^{+}$değeri ve SST $\mathrm{k}-\omega$ türbülans modeli ile mühimmat gövdesi üzerinde oluşan basınç ve hız profillerine ait veriler ileride AYSM'ye ait gövde, burun konisi ve kanatlarla ilgili olarak ileride yapılacak yapisal statik ve dinamik analizlerde kullanılacaktır.

Etik Kurul Onayı

Gerekli değil

\section{Simgeler}

$\mathrm{C}_{\mathrm{p}}$ : Özgül 1s1, J/kg.K

$\mathrm{F}_{1}$ : Karışım fonksiyonu

$\mathrm{g}$ : Yer çekimi ivmesi, $\mathrm{m} / \mathrm{s}^{2}$

$\mathrm{k}_{\mathrm{i}}$ : Is1 iletimi katsayıs1, W/m.K

$\mathrm{k}$ : Türbülans kinetik enerjisi, $\mathrm{m}^{2} / \mathrm{s}^{2}$

P: Basınç, Pa

q: Is1 ak1s1, W/m²

Re: Reynolds sayıs1 (=VLc/v)

T: Sicaklık, K

$\mathrm{u}: \mathrm{x}$ yönündeki hız, $\mathrm{m} / \mathrm{s}$

$\bar{u}:$ X yönündeki ortalama hız, $\mathrm{m} / \mathrm{s}$

$u^{\prime}$ : Hızın x yönündeki salınım değeri, $\mathrm{m} / \mathrm{s}$

v: Y yönündeki hız, $\mathrm{m} / \mathrm{s}$

$\bar{v}:$ Y yönündeki ortalama hız, $\mathrm{m} / \mathrm{s}$

$y^{\prime}$ : Hızın y yönündeki salınım değeri, $\mathrm{m} / \mathrm{s}$

kt: Türbülanslı eddy iletkenliği

$\mathrm{k}$ : Türbülans kinetik enerjisi $\mathrm{m}^{2} \cdot \mathrm{s}^{-2}$

v: Kinematik viskozite, $\mathrm{m}^{2} / \mathrm{s}$

$\varepsilon$ : Türbülans kinetik enerji yayılma hızı, $\mathrm{m}^{2} / \mathrm{s}^{3}$

$\mu$ : Dinamik viskozite, Pa.s

$\mu_{t}$ : Türbülanslı eddy viskozitesi, Pa.s

$\rho$ : Yoğunluk, $\mathrm{kg} / \mathrm{m}^{3}$

$\omega$ : Türbülans kinetik enerji özgül yayılma hızı

$\Phi$ : Türbülans kinetik enerji üretimi

$V_{\infty}:$ Akış hızı m/s

$\mathrm{L}_{\mathrm{c}}$ : Mühimmat uzunluğu $\mathrm{m}$

$\mathrm{C}_{\mathrm{f}}$ : Yüzey sürtünme katsayıs1

$\mathrm{T}_{\mathrm{w}}$ : Cidar kayma gerilmesi $\mathrm{kg} / \mathrm{m} . \mathrm{s}^{2}$

$\mathrm{U}_{*:}$ Sürtünme hızı m/s

y: İlk inflation katmanı kalınlığı m

\section{Kaynaklar}

[1] European Commission, Directorate-General for Research and Innovation, "Forest FiresSparking fire smart policies in the EU," Publications Office of the European Union, Luxembourg 2018.

[2] R. Hall, "Essentials of Fire Fighting," Fire Protection Publications, Fourth Edition. Stillwater, OK, 1998.

[3] A. Küçükosmanoğlu, "Türkiye Orman Yangınlarına Ait Bazı Verilerin Değerlendirilmesi," İstanbul Üniversitesi Orman Fakültesi Dergisi, 43, 94, 1993.

[4] M. Pulicinski, J. Gould, "The Effectiveness and Efficiency of Aerial Firefighting in 
Australia," (Technical Report Number A0701), University of Melbourne, Department of Environment and Conservation, Melbourne, Australia 2007.

[5] R. Alder, "Fighting Bush fires from the air", Paper presented at the Conference of the Institute of Fire Engineers, Adelaide, 1990.

[6] S. Dowling, "The jaw-dropping missions of fire-fighting pilots", https://www.bbc.com/future/article/2015082 1-the-jaw-dropping-missions-of-firefighting-pilots. [Erişim Tarihi: 19-Mart2021].

[7] V. K. Korenkov, "ASP-500 Fireextinguishing Air System", Revue Militaire Suisse, 149, 32, 2004.

[8] Z. Lei, China Daily, "Chinese rockets aimed at high-rise fires", https://www.chinadaily.com.cn/china/201702/14/content_28190425.htm. [Erişim Tarihi: 19-Mart-2021].

[9] A. H. Purcell, "Bombing' Forest Fires: A Proposed Technology," Environmental Conservation, 11(2), 183-183, 1984.

[10] H. Houghton, "F1 in Schools Car Design Simulation Tutorial," Autodesk Flow Design, 5,2014 .

[11] S. Geçim, E. Pulat, M. K. İşman ve A. E. Etemoğlu, "Çarpan dikdörtgen bir hava jetinde türbülans modellerinin karşılaştırılması ve ilgili parametrelerin 1s1 transferine etkileri," Uludağ Üniversitesi Mühendislik-Mimarlık Fakültesi Dergisi, Cilt 13, Say1 2, 2008.
[12] FLUENT, Fluent User's Guide, Lebanon, NH: Fluent Incorporated, 2006.

[13] B.E. Launder, D.B. Spalding, "The numerical computation of turbulent flows," Computer Methods in Applied Mechanics and Engineering, Volume 3, Issue 2, 1974, 269289.

[14] F. R. Menter, "Two-equation eddy-viscosity turbulence models for engineering applications," AIAA Journal, 32, 1598-1605, 1994.

[15] CFD Online, "CFD-Online.com." https://www.cfd-online.com/Wiki/SST_komega_model. [Erişim Tarihi: 19-Mart2021].

[16] D. C. Wilcox, "Reassessment of the scaledetermining equation for advanced turbulence models," AIAA Journal, 26, 1299-1310, 1998.

[17] Ansys Fluent 14.0: Theory Guide, ANSYS, Inc., 275 Technology Drive Canonsburg, PA $15317,2011$.

[18] L. V. Krishnamoorthy, D. R. Kirk, R. Glass, "Aerodynamic Database for the Mk 82 General Purpose Low Drag Bomb," DSTOTR-0554, Canberra (Australia), Defence Science and Technology Organization, 1997. 